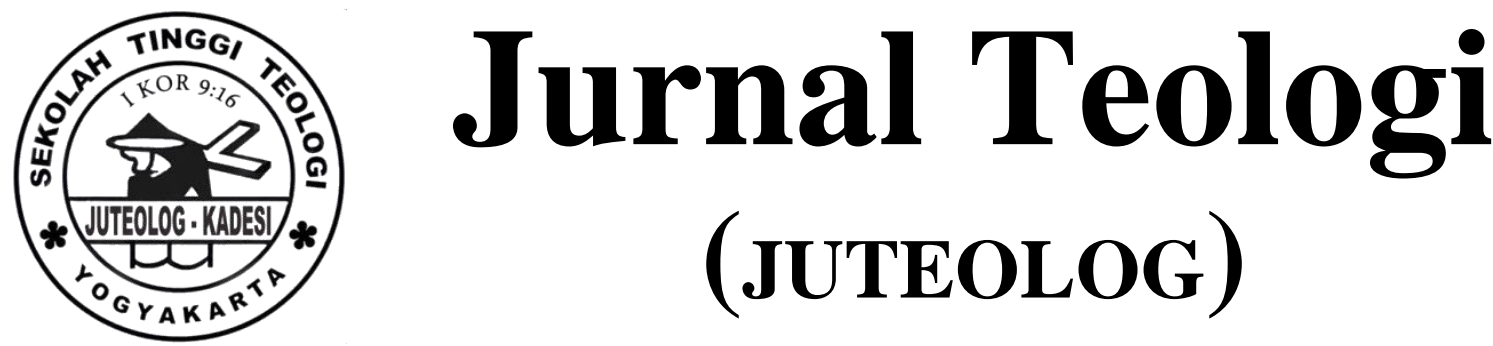

Vol. 1 No. 1 (December 2020) hlm. 81-99

Jurnal Teologi (JUTEOLOG)

e-ISSN 2775-4006

https://ejurnal.sttkadesiyogyakarta.ac.id/index.php/juteolog

p-ISSN 2774-9355

https://doi.org/10.52489/juteolog.v1i1.12

\title{
Ketahanan Iman Kristen di Tengah Era Disrupsi
}

Yakub Hendrawan Perangin Angin 1), Tri Astuti Yeniretnowati ${ }^{2)}$

yakub.hendrawan@sttbetheltheway.ac.id

\section{Recommended Citation}

Turabian $8^{\text {th }}$ edition (full note)

Yakub Hendrawan Perangin Angin and Tri Astuti Yeniretnowati, "Ketahanan Iman Kristen Di Tengah Era Disrupsi," Jurnal Teologi (JUTEOLOG) 1, no. 1 (December 29, 2020): 1, accessed August 13, 2021, https://ejurnal.sttkadesiyogyakarta.ac.id/index.php/juteolog/article/view/12.

American Psychological Association $7^{\text {th }}$ edition

(Angin \& Yeniretnowati, 2020, p. 1)

Received: 29 December 2020

Accepted:26 December 2020

Published:29 December 2020

This Article is brought to you for free and open access by Sekolah Tinggi Teologi Kadesi Yogyakarta. It has been accepted for inclusion in Christian Perspectives in Education by an authorized editor of Jurnal Teologi (JUTEOLOG).

For more information, please contact juniorichson1995@gmail.com 


\begin{abstract}
Christian Faith Resilience Amidst the Era of Disruption. The current era of disruption which is marked by the birth of various innovations and new technologies cannot be avoided by all people, organizations and churches. The era of disruption will affect the Christian faith, so that the attitudes, policies and culture adopted by believers who are Christian to the influence caused by this era of disruption will greatly determine the continuity of their Christian faith, whether it will continue to grow or will die completely. With a descriptive qualitative method with a literature study approach, the author proposes a conceptual frame of the role of the challenge of Christian faith in the era of disruption. The main source of analysis includes research results contained in journals and books, which are analyzed by looking at the relationship and compatibility with the title of the writing. The results of this study on the era of disruption and dimensions of Christian faith are then used to formulate the concept of resilience of the Christian faith in the era of disruption. There are eight main attitudes that must be developed in order to maintain Christian faith in this era of disruption.
\end{abstract}

Keywords: Resilience, Christian Faith, Disruption.

\begin{abstract}
Abstrak
Ketahanan Iman Kristen Di Tengah Era Disrupsi. Era disrupsi yang berlangsung saat ini yang ditandai dengan lahirnya berbagai inovasi dan teknologi baru tidak dapat dihindari oleh semua orang, organisasi dan gereja. Era disruspsi akan berpengaruh kepada iman Kristen, sehingga sikap, kebijakan serta budaya yang diambil oleh orang percaya yang ber-iman Kristen terhadap pengaruh yang ditimbulkan oleh era disrupsi ini sangat menentukan keberlangsungan iman Kristen-nya apakah akan kokoh terus berkembang atau akan mati total. Dengan metode kualitatif deskriptif dengan pendekatan studi literatur penulis mengemukakan sebuah bingkai konsep peran tantangan iman Kristen pada era disrupsi. Adapun sumber utama dari analisis meliputi hasil penelitian yang terdapat pada jurnal dan buku, yang dianalisis dengan cara mencermati hubungan dan kecocokan dengan judul penulisan. Hasil kajian tentang era disrupsi dan dimensi-dimensi iman Kristen ini selanjutnya digunakan untuk menyusun konsep ketahanan iman Kristen pada era disrupsi. Terdapat delapan sikap utama yang harus dikembangkan guna mempertahankan iman Kristen di era disrupsi ini.
\end{abstract}

Kata kunci: Ketahanan, Iman Kristen, Disrupsi.

\title{
PENDAHULUAN
}

Era disrupsi adalah era dimana perubahan terjadi sedemikian tidak terduga, mendasar yang meliputi hampir semua aspek kehidupan. Tanda utamanya adalah tatatan baru hadir menggantikan tatanan lama yang sudah tidak lagi sesuai dengan tuntutan zaman (Bashori 2018). Setiap tahapan revolusi industri memiliki tekanan utama perbedaan yaitu dimulai dari revolusi industri 1.0 abad ke 18 dengan penemuan mesin uap, yang memungkinkan barang dapat diproduksi secara masal, revolusi industri 2.0 abad ke 19-20 ditandai oleh penggunaan 
listrik sehingga biaya produksi menjadi murah, revolusi industri 3.0 sekitar tahun 1970an dengan mulai banyaknya penggunaan komputerisasi, dan revolusi industri 4.0 terjadi tahun 2010an melalui rekayasa intelegensia dan internet of thing (Diana, Rahmi, Faidatul Hasanah, Restu Presta Mori 2019).

Dalam menghadapi era disrupsi ini, para pemimpin umat serta semua orang percaya sangat tertantang karena era revolusi industri 4.0 ini juga akan mendisrupsi berbagai bidang kehidupan umat manusia, juga kepercayaan iman Kristen, sehingga para pemimpin umat dan semua orang percaya yang memiliki iman Kristen wajib memastikan revolusi industri 4.0 tidak mendegradasi dan memarginalkan keutamaan serta sifat paling dasar manusia, moral, dan karakter, serta iman, khususnya pengikut Kristus, umat atau jemaat. Hal ini tidaklah ringan, mengingat kemajuan teknologi informasi menuntut kepiawaian dan daya saing lebih.

Sebagai orang yang beriman kepada Tuhan Yesus, maka ketahanan iman di tengah zaman yang terus berkembang yang saat ini memasuki era disrupsi ini menjadi hal yang sangat penting dan banyak menyita perhatian para pemimpin umat atau gereja serta berbagai organisasi pelayanan Kristen, sehingga pada penulisan artikel atau makalah ini akan dilakukan pembahasan terkait apa sebenarnya yang dimaksud dengan era disrupsi? apa saja ciri-cirinya? apa dampak yang dipaparkannya? lalu bagaimana Iman Kristen mensikapi era disrupsi ini?.

\section{METODE}

Analisis dilakukan dengan tinjauan pustaka, yaitu dengan cara menganalisis tentang era disrupsi sebagai sebuah kerangka konsep peran tantangan iman Kristen pada era disrupsi. Sumber utama dari analisis adalah beberapa sumber relevan, hasil penelitian dari jurnal dan buku yang sesuai dengan pembahasan. Semua sumber selanjutnya dianalisis dengan cara mencermati hubungan dan kecocokan dengan tema penulisan yaitu ketahanan iman Kristen di era disrupsi. Hasil kajian tentang era disrupsi dan prinsip-prinsip serta dimensi-dimensi iman Kristen ini disusun menjadi konsep ketahanan iman Kristen di tengah era disrupsi (Ronda 2019).Hasil analisis selanjutnya diuraikan secara deskriptif dan sistematis. Tulisan ini diharapkan memberikan bingkai teologis bagaimana kita sebagai orang percaya yang beriman Kristen menjawab tantangan zaman di era disrupsi (Zaluchu 2020). 


\section{PEMBAHASAN}

\section{Hakikat Ketahanan, iman.}

Kata ketahanan berdasarkan kamus bahasa Indonesia, asal katanya tahan yang artinya: (1) tetap keadaanya meskipun mengalami berbagai-bagai hal; (2) kuasa (kuat) menderita atau menanggung sesuatu; (3) betah; dapat menyabarkan; dapat menguasai dirinya; (4) tidak lekas merasa jijik. Sehingga arti kata ketahanan dapat disimpulkan menjadi perihal tahan; kekuatan hati; kebetahan; kesabaran dsb (Poerwadarminta 1985).

Iman merupakan satu konsepsi yang sangat penting penting dalam seluruh Perjanjian Baru. Iman ditunjukkan dengan membuang segala kepercayaan pada sumber-sumber yang berasal dari kekuatan sendiri. Iman dapat juga diartikan pasrah menyerahkan diri sendiri tanpa syarat apapun kepada anugerah Allah. Iman berarti juga memegang teguh janji Allah di dalam Tuhan Yesus Kristus dengan menggantungkan kepercayaan sepenuhnya kepada karya Kristus, dan kepada kekuasaan Roh Kudus yang menuntun kehidupan sehari-hari. Dan juga Roh Kudus menuntun kepada seluruh kebenaran Allah, sehingga orang yang dituntunnya terhindar dari siasat penyesatan (Arifianto and sumiwi Rachmani 2020). Sehingga akhirnya Iman juga mencakup kepercayaan dan ketaatan mutlak kepada Allah. Yang dimaksud dengan iman yang benar menurut Alkitab adalah ketaatan yang penuh keyakinan kepada Firman Tuhan dalam situasi dan kondisi apapun. Perjanjian Baru memberi pengertian iman adalah menunjukkan sikap mengandalkan Tuhan. Iman yang benar menghasilkan perbuatan yang benar. Iman dikatakan mati jika tanpa ketaatan dan tanpa penuh keyakinan kepada Firman Allah sebagaimana dinyatakan dalam Yakobus 2:17 "jika iman tidak disertai perbuatan, maka iman itu pada hakikatnya mati”. Sedangkan dalam Ibrani 11:1 iman Kristen memberikan keyakinan dan jaminan bahwa ia akan dapat bertahan (Gea 2020).

Istilah Kristen terdapat dalam Kisah Para Rasul 11:26; Kisah Para Rasul 26:28; dan 1 Petrus 4:16. Ketiga ayat ini mengandung gagasan bahwa Kristen merupakan gelar pada zaman masa Perjanjian Baru yang diakui secara umum, Walaupun istilah 'Kristen' pada awalnya merupakan sebuah nama ejekan, namun seiring dengan berjalannya waktu orang percaya mau tidak mau ditantang untuk memberikan jawab atas pertanyaan 'Apakah kamu Kristen?' Sehingga bukanlah sebuah nama kehinaan. Faktanya nama itu mempunyai kelayakan tertentu: dimana istilah Kristen memusatkan perhatian kepada Pribadi Tuhan Yesus Kristus

Kata disrupsi dalam bahasa Inggris disruption adalah kata benda yang berarti gangguan, kekacauan (Echols 1990). Sedangkan dalam kkbi.web.id kata disrupsi berarti hal 
tercabut dari akarnya Revolusi industri dimulai dari industri 1.0, 2.0, 3.0, sampai 4.0. Dimana fase industri merupakan real change dari perubahan yang ada. Tanda dari Industri 1.0 adalah mekanisasi produksi untuk menunjang efektifitas dan efisiensi aktivitas manusia, sedangkan tanda dari industri 2.0 adanya produksi massal dan dimulainya standarisasi mutu, sedangkan tanda dari industri 3.0 adanya penyesuaian massal dan fleksibilitas manufaktur yang berbasis otomasi dan robot. Akhirnya Industri 4.0 ditandai dengan cyber fisik dan kolaborasi manufaktur Istilah industri 4.0 berasal dari sebuah proyek yang diprakarsai oleh pemerintah Jerman untuk mempromosikan komputerisasi manufaktur (Sutrisna 2018). Hal yang sama dijelaskan oleh RISTEKDIKTI, dimana ciri-ciri era disrupsi dapat dijelaskan dengan istilah VUCA yaitu: Pertama, Volatitily yaitu perubahan yang massif, cepat, dengan pola yang sulit ditebak. Kedua, Uncertainty, yaitu perubahan yang cepat menyebabkan ketidak pastian. Ketiga, Complexity, dimana terjadinya kompleksitas hubungan antar faktor penyebab perubahan. Keempat, Ambiguity, dimana kekurangjelasan arah perubahan yang menyebabkan ambiguitas. Sehingga pada era disrupsi teknologi informasi menjadi basis atau dasar dalam kehidupan manusia, bahkan di dunia saat ini sudah memasuki era revolusi sosial industri 5.0 (Diana, Rahmi, Faidatul Hasanah, Restu Presta Mori 2019).

Disruption dapat dikatakan pada dasarnya adalah perubahan. Perubahan yang terjadi karena hadirnya masa depan ke masa kini, yang membuat segala sesuatu yang pada awalnya berjalan normal dengan seketika berubah akibat hadirnya sesuatu yang baru, apakah itu berupa teknologi baru, proses bisnis yang baru, para pemain baru, aplikasi yang baru, model bisnis yang baru, atau kombinasi dari berbagai faktor tersebut (Rahayu 2018). Dapat dikatakan industri 4.0 adalah nama tren otomasi yang merupakan pertukaran data terkini dalam teknologi manufaktur.

\section{Peluang dan Tantangan Era Disrupsi}

Tantangan yang sangat penting saat memasuki era revolusi industri adalah berkembangnya teknologi informasi yang sangat mempengaruhi perkembangan manusia dari semua kelompok usia. Revolusi industri juga dikatakan oleh Ruat Diana (2019), dapat menghasilkan persaingan antar manusia menjadi semakin tajam, lebih lanjut dikatakan juga revolusi industri ini akan ditandai dengan adanya kecerdasan buatan yang diintegrasikan dalam mesin (Diana 2019). Revolusi industri 4.0 berdampak pada manusia baik dalam hal cara manusia dalam memandang hidup, bekerja, dan berhubungan dengan sesamanya bahkan dalam relasinya bersama Allah. Revolusi industri 4.0 mampu mengubah secara radikal 
kehidupan manusia, baik cara kerjanya, dan cara berpikir serta mempengaruhi dalam cara berelasi. Dapat juga dikatakan bahwa era disrupsi ini mempengaruhi setiap bidang kehidupan manusia termasuk dalam kehidupan imannya, dimana imam dapat dipengaruhi oleh dampak yang diakibatkan oleh era disrupsi yaitu revolusi industri 4.0 (Njo 2020).

Revolusi industri 4.0 juga telah memberikan pengaruh besar dalam kehidupan manusia termasuk dalam sistem pendidikan Kristen. Pendidikan Kristen harus dapat melihat peluang untuk turut serta dalam mengembangkan sistem pendidikan. Terdapat empat kemampuan (capability) yang dibutuhkan pada era disrupsi 4.0 ini, yaitu: kemampuan yang terkait dengan spesialisasi, kapabilitas untuk mengatur pihak-pihak terkait, kapabilitas untuk memecahkan masalah, dan kapabilitas untuk mengembangkan orang. Pendidikan Kristen pada semua level pendidikan dapat mengadopsinya dan memodifikasinya dengan cara menambahkan beberapa hal terkait kompetensi untuk melakukan tindakan revolusi (Widiatna 2020) Era disrupsi dapat dilihat dari berbagai perubahan yang terjadi dengan sangat cepatnya. Era disrupsi juga menghasilkan suatu kemudahan aksesibilitas dimana berbagai hal saling terhubung guna membantu kebutuhan manusia. Sehingga era disrupi ini juga menantang iman Kristen. Era disrupsi ini memberikan peluang dalam mendorong kekristenan agar kreatif dalam melaksanakan berbagai rutinitas keimanannya dan keagamaannya (Panuntun 2020). Terlebih orang percaya di era disrupsi seperti ini harus memberikan makna kehidupan yang selaras dengan Firman Tuhan dalam mengupayakan kehidupan, dan membawa pesan kebaikan bagi sesama (Arifianto, Triposa, and Supriyadi 2020).

Semua perubahan teknologi tentunya terjadi dengan sangat cepat, dimana konsekuensinya memiliki dampak apakah positif juga kelemahan yang dapat saja dikategorikan berbahaya. Dimana dengan adanya perubahan yang sangat cepat ini dapat menghasilkan kejutan budaya yang mana manusia masuk dalam kegamangan bagaimana bersikap dan mempertahankan imannya. Paling tidak ada beberapa manfaat dampak positif dari perkembangan dunia digital, yaitu: Pertama, melalui adanya aplikasi yang terdapat dalam smartphone dan dunia daring, tentunya sangat mempermudah berbagai hal kegiatan umat manusia terutama dalam bidang ekonomi, perdagangan, keuangan, kesehatan, komunikasi, pendidikan, dan keagamaan. Kedua, pada saat ini perangkat teknologi informasi dan internet sudah menjadi sumber yang sangat penting dan mempengaruhi pendidikan dan bukan hanya informasi dalam mendapatkan berita saja, tetapi juga ilmu pengetahuan, seni, keagamaan dan segala jenis informasi lainnya yang diperlukan dapat ditelusuri melalui berbagai mesin pencari, diantaranya dapat melalui mesin "Google" dan "YouTube". 
Ketiga, umat manusia saat ini juga banyak tergabung masuk dalam kelompok atau komunitas-komunitas baru yang sering juga disebut dengan istilah warganet, seperti "Facebook", "Whatsapps" atau "Instagram" dan media online jejaring sosial lainnya yang terus menerus berkembang bahkan ada yang khusus aplikasi media sosial sesuai kategori apakah profesi, umur, gender bahkan hobi. Keempat, perangkat digital saat ini dapat menjadi salah satu sarana yang sangat efektif bagi pelayanan baik gereja maupun organisasi pelayanan iman Kristen lainnya bahkan oleh pribadi sekalipun karena dapat dilakukan oleh siapa saja, dari mana saja tanpa harus terpaku pada satu tempat tertentu saja dan waktunya bisa kapan saja (Ronda 2019).

Dunia teknologi digital pada era disrupsi yang begitu banyak manfaatnya tidak terlepas dari dampak berbahaya yang ditimbulkannya, diantaranya adalah: Pertama, informasi dan pengetahuan banyak juga yang tidak benar atau palsu (hoaks), mengandung konten negatif apakah itu mengandung pornografi, dan kekerasan, serta berita sampah yang tidak membangun iman. Kedua, kehadiran budaya baru khususnya dikalangan generasi anak muda saat ini khususnya yang berupa berbagai bahasa dan istilah baru yang sebelumnya tidak dikenal sekarang menjadi popular dengan cepat. Ketiga, dalam komunikasi antar warga jejaring sosial tidak jarang muncul budaya kekerasan bahkan saling mencaci maki. Keempat, timbulnya budaya topeng atau kemunafikan dimana semua ini menjadi ciri khas manusia di era digital sehingga sudah tidak dapat diketahui lagi mana yang benar atau mana yang palsu. Kelima, kejahatan berkembang luar biasa apakah dilakukan sendiri dalam artian tunggal atau dilakukan secara bersama-sama komplotan bahkan banyak yang tadinya tidak tahu cara berbuat kejahatan bisa mempelajarinya melalui berita yang terkandung dalam di media sosial bahkan ada tutorialnya. Keenam, banyak orang terlena karena hiburan dan fasilitas yang ditawarkan dalam media sosial ini sehingga banyak waktu terpakai untuk menonton film atau membaca serta melihat berita-berita yang tersaja di media sosial ini dimana tidak sedikit kontennya yang berbahaya bagi iman seseorang, bahkan dapat menggerus dan mematikan iman percayanya (Ronda 2019).

\section{Ketahanan Iman Kristen}

Iman tidak dapat dikalahkan oleh pertimbangan akal, iman tidak dapat diancam oleh perkiraan-perkiraan sehat manusia. Sejarah Perjanjian Lama mencatat dan memberi kesaksian iman yang hidup, yang nyata di dalam beberapa tokoh bangsa Yahudi, sebagaimana diceritakan dalam surat kepada orang Ibrani. Surat Ibrani ini ditujukan kepada jemaat yang 
keadaannya sangat memprihatinkan. Disebutkan bahwa mereka bertindak sangat lamban (Ibr. 5:11) dan berada dalam keadaan putus asa (Ibr. 12:3). Yang lebih parah adalah bahwa mereka kehilangan semangat iman yang semula (Ibr. 10:23, 35). Mereka gagal untuk bertumbuh dan berkembang dan oleh karenanya perlu diperingatkan untuk meneladani iman dari saudara Kristen mereka yang telah meninggal (Ibr. 13:7). Oleh karena itu surat Ibrani bertujuan untuk menyadarkan pembacanya akan janji-janji Tuhan yang digenapi dalam Kristus dan jawaban yang diharapkan dari manusia, yaitu ketabahan iman dalam perjalanan hidup di dunia ini.(Baker 1991)

Definisi Iman dapat diartikan dengan beberapa ugkapan yaitu : pertama, sebagai suatu kepercayaan yang teguh kepada Allah dan Kristus tanpa keraguan sedikitpun. Kedua, berarti meyakinan akan janji-janji Allah. Ketiga merupakan sarana untuk meresponi akan anugerah keselamatan dari Allah. Keempat sebagai sarana untuk pembenaran orang percaya dan dasar pembenaran adalah Kristus. Kelima, iman yang membenarkan dan menyelamatkan adalah iman yang bersumber dan berdasar kepada Kristus. Keenam, iman yang benar selalu nyata dalam perbuatan yang baik sebagai buah iman yang sejati. Konsep iman yang digambarkan dalam kitab Yakobus adalah iman yang sejati, iman yang aktif dan iman yang bertindak, berbuat serta menerima.(Jawamara 2020)

\section{Berbagai pandangan para teolog terkait iman Kristen}

Kekristenan merupakan suatu iman, karena didasarkan pada pengetahuan yang dinyatakan oleh Allah. R.C. Sproul memberikan beberapa pernyataan mengenai iman yaitu: Pertama, iman merupakan suatu kepercayaan di dalam Allah yang membawa kita dari tempat yang gelap berpindah kepada terang. Kedua, iman didasarkan pada alasan yang sah dan juga dapat dipertanggungjawabkan serta bukti historis. Ketiga, iman menyediakan substansi untuk terus berpengharapan akan masa mendatang. Keempat, iman mempercayai sesuatu yang tidak kelihatan. Kelima, iman berarti mempercayai Allah.(Sproul 2018)

Iman Kristen dapat dikatakan sebagai pemberian atau anugerah Allah. Isi utama dari iman Kristen adalah Allah dan karya penyelamatanNya. Atau lebih khusus: isi iman Kristen ialah Yesus Kristus yang mati dan yang bangkit (Rm 10:9). Jadi iman Kristen adalah jawaban manusia atas karya (=tindakan, perbuatan) Allah. Itu berarti, bahwa tanpa karya Allah, tanpa inisiatif dari pihakNya, tidak mungkin ada iman. Iman hanya ada, karena iman ditimbulkan oleh Allah: oleh karyaNya. Pemberian atau anugerah Allah tidak membuat manusia menjadi pasif. Karena itu untuk mengerti apa itu iman Kristen, kita harus mengetahui dahulu apa yang 
dipercayai oleh iman Kristen. Isi iman Kristen hanya dapat kita ketahui dari sejarah - sejarah selamat - yang di dalamnya Allah menyatakan diriNya. Karena itu teologia Kristen tidak hanya berkata-kata tentang "Allah" dalam arti umum, tetapi ia terutama berkata-kata tentang Allah dalam arti yang khusus, yaitu Allah sebagai "Allah Abraham, Ishak dan Yakub”, atau lebih khusus sebagai “Allah dan Bapa Yesus Kristus”. Theologia Kristen berkata-kata tentang Allah ini, karena teologia Kristen menceritakan suatu sejarah. Pengetahuan Teologia Kristen tentang Allah ialah pengetahuan yang dilahirkan oleh suatu sejarah. Jadi pengetahuan akan Allah timbul dari penyataan Allah, bukan dari pengetahuan manusia yang bersifat umum (Abineno J.L.Ch. 1993).

Isi kepercayaan (iman) ialah Kristus, Anak Allah, Juruselamat. Pecaya ialah pertamatama: Mengakui bahwa hal itu benar. Pekerjaan mengakui, mengharuskan adanya pengakuan dari "aku orang", pengakuan adalah menaklukan diri. Perintah dari rasul-rasul kepada orangorang yang mendengar Injil, pertama-tama ialah: percayalah dan engkau akan selamat (Kis. 16:31). Di dalam percaya (iman): makin luas pengetahuan kita, makin banyak sebab-sebab untuk memuliakan nama-Nya. Inilah yang menjadi tujuan yang tertinggi. Rasul Paulus menekankan iman yaitu mengenakan kepada diri sendiri (Rm. 3:22; Gal. 2:16; Ef. 3:12; 2 Tes. 2:13). Yakobus menyatakan bahwa percaya (iman) harus berakibat perbuatan baik. Tidak ada percaya yang tidak keluar di dalam perbuatan yang baik. Tentu saja ini tidak berarti bahwa Yakobus memandang perbuatan baik sebagai alat untuk mencapai keselamatan, akan tetapi memang percaya tidak dapat tersembunyi saja, akan tetapi tentu keluar. Lagi pula kita jangan melupakan, bahwa yang memberikan kepercayaan (iman) adalah Tuhan (Mat. 16:17; 1 Kor. 12:3).(Soedarmo 2011)

Hakekat kehidupan iman Kristen berangkat dari keselamatan yang dikerjakan Tuhan Yesus Kristus di kayu salib. Keselamatan yang diterima oleh orang percaya adalah karena anugerah semata-mata, dan sama sekali bukan karena perbuatan baik atau jasa yang dilakukan, hal ini mengandung arti tidak dimulai dari amal kebajikan umat manusia (lih. Ef. 2:8). Dengan kata lain beriman juga dapat berarti memiliki kesepakatan dengan Tuhan. Dimana kesepakatan bersama Tuhan ini menuntut segenap hidup dari orang percaya yang dipersembahkan hanya bagi Tuhan saja. Dengan demikian, jikalau seseorang yang beriman kepada Kristus Yesus sudah bersedia melakukan kesepakatan dengan Tuhan, maka tidak ada lagi yang boleh disisakan dalam hidupnya untuk kepentingan dan kemuliaan diri sendiri. Hal ini sesuai dengan apa yang dinyatakan oleh Firman Tuhan bahwa setelah umat manusia ditebus oleh darah Yesus, maka berarti orang tersebut telah dibeli dengan harga yang lunas 
dibayar, bahwa orang tersebut sudah tidak lagi memiliki diri sendiri (1Kor. 6:19-20). Iman tidak dapat terwujud, berkembang, bertumbuh, dan berbuah serta menjadi sempurna seperti Tuhan Yesus jika tanpa adanya kesediaan dan kerelaan untuk melepaskan beban dan dosa dengan terus meneladani seluruh gaya hidup dan jejak Tuhan Yesus (Ibr. 12:1-2). Melepaskan beban dan dosa yang dimaksud disis dapat berarti melepaskan semua keterikatan dengan kesenangan dunia ini dan semua keinginan yang bertentangan dengan kesucian Allah.(Sabdono 2018b)

Agar dapat menjadi umat pilihan berdasarkan iman memerlukan perjuangan, sebab iman tidak dapat terjadi hanya dengan sebuah pengaminan akali atau persetujuan pikiran saja namun iman adalah tindakan nyata, dimana seseorang harus hidup dalam penurutan dan pengiringan terhadap kehendak Tuhan saja. Orang yang menolak hidup dalam penurutan dan pengiringan kehendak Tuhan, dapat dikatakan menolak untuk beriman. Kekristenan adalah jalan Tuhan, bagaimana seseorang memiliki dan menyatakan karakter Tuhan di dalam hidupnya. Itulah sebabnya orang percaya yang beriman kepada Tuhan Yesus harus memiliki pikiran dan perasaan seperti Yesus Kristus. Hanya kasih karunia dalam Yesus Kristus yang mampu membawa seseorang pada kehidupan yang tak bercacat dan tidak bercela atau dapat dikatakan sempurna seperti Bapa (Mat. 5:48) (Sabdono 2018a).

Iman Kristen merupakan hasil dari proses kepercayaan seseorang terhadap Yesus Kristus. Iman tidak dapat terbentuk secara instan apalagi tanpa disertai perjuangan, tetapi iman terbentuk dari setiap ujian, pencobaan, dan juga penderitaan yang di alami. Sebagaimana sudah terbukti jelas dari kehidupan iman yang ditunjukkan oleh jemaat mulamula yang mengalami penganiayaan-penganiayaan yang begitu hebat. Sehingga jika orang Kristen mengatakan beriman, maka harus siap menghadapi setiap pencobaan serta tantangan yang terjadi di dalam kehidupannya. Dengan kata lain Iman harus diwujudnyatakan dengan perbuatan, karena tanpa iman tidak mungkin seseorang berkenan bagi Tuhan.(Nathanael et al. 2020)

Menurut Thomas H. Groome dalam bukunya Pendidikan Agama Kristen, mengatakan bahwa Iman Kristen sebagai realitas yang hidup paling tidak memiliki tiga dimensi yang sangat esensial, yaitu: kesatu, keyakinan, kedua, hubungan yang penuh kepercayaan, dan ketiga, kehidupan agape yang hidup. Mempertimbangkan bahwa kita di sini sedang membicarakan secara khusus mengenai iman Kristen, dan iman ini sebagai realitas yang hidup, ketiga dimensi ini dinyatakan dalam kegiatan iman sebagai : kesatu, percaya (faith as 
believing), kedua, mempercayakan (faith as trusting), dan ketiga, melakukan (faith as doing). Iman sebagai Kegiatan Percaya (Groome 2017).

\section{Bagaimana Membangun dan Mempertahankan Ketahanan Iman Kristen di Tengah Era Disrupsi}

Berbagai definisi ketahanan atau ketangguhan, merujuk pada respons terhadap penderitaan, tekanan atau kesulitan. Agar menjadi tangguh, kita perlu mengalami masa-masa yang penuh tantangan. Lewat menghadapi berbagai tantangan itulah, kita mengembangkan ketangguhan mental. Seokor kupu-kupu perlu berjuang untuk keluar dari kepompongnya. Jika seseorang menolongnya, ia kemungkinan tidak akan pernah bisa terbang, karena kupukupu memerlukan perjuangan tersebut supaya sayapnya menjadi kuat. Serupa dengan itu, kita perlu berjuang untuk menjadi lebih kuat sebagai manusia terlebih seorang yang ber-iman Kristen Setiap bidang itu penting, namun aspek rohani dari ketangguhan adalah kunci (Horsfall 2020).

Sikap yang harus ada, dibangun terus-menerus dan diperagakan dalam mewujudnyatakan iman Kristen di tengah era disrupsi ini paling tidak adalah:

\section{Percaya Kepada Tuhan}

Semua orang semua mengalami kesulitan hidup dalam berbagai bentuk dan waktu yang berbeda. Seperti yang sering dikatakan, "Hidup ini sulit”. Hidup ini sering kali menyakitkan. Hidup sering kali melukai. Beberapa kesulitan tidaklah berat. Beberapa kesulitan terjadi mendadak dan menghancurkan. Kesulitan lainnya bisa menjadi berat dan terus menerus, seperti cacat fisik yang tidak dapat disembuhkan. Bagian utama dari pertumbuhan rohani adalah belajar mempercayai Allah pada saat-saat sulit. Penting bagi orang percaya untuk menaati Tuhan, dan sama pentingnya juga untuk mempercayai-Nya. Dalam rangka mempercayai Tuhan, orang percaya harus selalu melihat kesulitan-kesulitan yang dialami melalui mata iman, bukan melalui indera. Sama seperti halnya iman keselamatan datang melalui pendengaran akan berita Injil (Roma 10:17), demikian juga iman untuk mempercayai Tuhan dalam masa-masa sulit datang melalui Firman Tuhan saja. Hanya di dalam Kitab Suci orang percaya bisa menemukan pandangan yang benar tentang hubungan dan keterlibatan Allah dalam keadaan-keadaan yang menyakitkannya. Hanya melalui penerapan ayat-ayat Firman Tuhan dalam hati oleh Roh Kuduslah orang percaya bisa menerima anugerah untuk mempercayai Tuhan dalam masa-masa sulit. Pada saat-saat penuh kesulitan, Alkitab 
mengajarkan tiga kebenaran penting tentang Allah - kebenaran-kebenaran yang harus dipercayai jika ingin mempercayai Dia dalam masa-masa sulit. Kebenaran-kebenaran tersebut adalah: Allah sungguh-sungguh berdaulat; Allah tidak terbatas dalam kebijaksanaan-Nya; Allah sempurna dalam kasih (Bridges 2013).

\section{Kesetiaan Menjalankan Iman}

Di dalam Perjanjian Baru, Yesus menunjukkan kesetiaan yang begitu indah kepada Bapa dan juga kepada umat yang mempercayai-Nya dengan menyelesaikan karya penebusan manusia di kayu salib. Dia tetap setia pada siapa Diri-Nya dan panggilan-Nya untuk membawa umat yang percaya kembali kepada Allah. Injil Lukas memberi keterangan ini tentang Yesus saat Dia bertumbuh menjadi pria dewasa: "Yesus makin bertambah besar dan bertambah hikmatNya dan besar-Nya, dan makin dikasihi oleh Allah dan manusia." (Lukas 2:52). Pemikiran pokok ayat ini mendorong untuk memahami bahwa kesetiaan dan komitmen kepada Allah akan menghasilkan kehidupan yang terbaik dari yang mungkin dapat dijalani - tidak bebas dari masalah dan pencobaan, tetapi konsisten berjalan di jalan yang benar menuju karakter dan sifat-sifat Allah Bapa. Orang yang beriman Kristen memilih untuk tetap tinggal di dalam-Nya bukan karena keharusan, tetapi karena kerinduan. Kesetiaan harus menjadi prioritas, tak peduli siapa yang sedang memperhatikan. Jika orang percaya sungguh-sungguh ingin berdampak pada orang lain bagi Kristus terlebih lagi pada masa era disrupsi ini atau era revolusi industri 4.0, maka kesetiaan harus menjadi lebih dari sekadar kualitas yang diinginkan; kesetiaan harus menjadi gaya hidup.(Frazee 2016)

\section{Mengenakan Gaya Hidup Yang Benar}

Orang yang beriman Kristen harus mengenakan gaya hidup yang menekankan kesucian seperti Tuhan dan fokus kepada agenda utama, yaitu Kerajaan Tuhan Yesus di langit baru dan bumi yang baru nanti. Selanjutnya, orang percaya harus berusaha melakukan segala sesuatu hanya untuk kepentingan Kerajaan Surga. Orang yang beriman kepada Kristus harus menemukan dan mengenakan pola hidup seperti yang Tuhan kehendaki untuk dikenakan, agar supaya hidupnya sungguh-sungguh dapat menghadirkan Allah dalam kehidupan manusianya setiap waktu karena hanya melalui cara ini saja orang yang beriman kepada Kristus dapat menjadi saksi yang sangat efektif dan sungguh-sungguh menyenangkan hati Tuhan, (Sabdono 2017) dan terlebih juga Yesus menegaskan bahwa kasih yang sejati harus 
disaksikan sebab praktik dan perilaku kasih dapat terlihat pada siapapun, terlebih pada “mereka” yang membutuhkan (Arifianto 2020a).

\section{Menerapkan Strategi Hidup Kristen}

Allah tentunya telah memiliki rencana indah dan baik bagi manusia di dunia ini dan Allah menunjukkannya dengan memberikan sejumlah kelengkapan seperti karunia rohani dan talenta agar setiap orang yang percaya kepada-Nya dapat menjalankan rencana Allah tersebut. Visi tersebut hanya dapat dicapai jika orang percaya kepada Yesus Kristus memiliki strategi hidup yang tepat. Strategi hidup pribadi ini menyangkut bagaimana cara dalam mengelola waktu, uang, talenta yang telah Allah berikan. Dengan mengelola apa yang telah Tuhan berikan maka orang percaya akan dapat menggunakan hidup ini secara maksimal sehingga dapat memuliakan-Nya, (Efesus 5:15-17; Matius 6:19-34; 1 Timotius 6:6-10; Matius 25:14-30).(Surabaya 2016). Untuk itu orang percaya harus memiliki sikap yang benar agar tidak terjebak dalam cinta akan uang. Sikap yang benar dalam pengelolaan uang adalah menjadikan uang untuk bersahabat dengan Tuhan, bukan sebaliknya. Jadi, motivasinya kalau orang percaya bekerja mencari uang semata-mata adalah karena mau melayani untuk kepentingan Tuhan saja. Tidak dapat terlepas dari belenggu cinta uang bisa berarti membawa diri sendiri bahkan orang lain kepada kegagalan mengalami dan memiliki keselamatan yang sejati. Ini dapat juga disebut sebagai dosa materialisme.(Sabdono 2017)

\section{Mampu Mengendalikan Stres}

Stres dapat menyebabkan masalah serius terhadap kesehatan seseorang termasuk orang percaya kepada Yesus, diantaranya dapat gangguan berupa tekanan darah tinggi, serangan sakit kepala dan penyakit maag, serta gangguan emosional. Dalam Filipi 4:2-9 Paulus dikisahkan bagaimana menghadapi hidup dengan begitu banyak hal yang dapat membuat stress. Paulus sedang berada dipenjara dengan kemungkinan menghadapi hukuman mati, disisi lain Paulus juga ada dalam situasi harus membela dirinya sendiri dari semua tuduhan dan tuntutan yang datang dari dalam gereja. Menghadapi persoalan dan tekanan ini Paulus dapat hidup secara luar biasa dalam keadaan damai dan sukacita. Ternyata dari Filipi 4:2-9 ada kunci rahasia Paulus, yaitu bagaimana Paulus memiliki sikap dan menghadapi keadaan apapun yang dialaminya dengan terus memikirkan apa yang benar, apa yang mulia, apa yang adil, apa yang suci, apa yang manis, apa yang sedap didengar, kebajikan dan yang patut 
dipuji ternyata terbukti dapat menolong membersihkan pikiran dan mengembalikan ketenangan diri.(Baker 2013)

\section{Menjadi Pekerja Keras dan Cerdas}

Orang percaya yang memiliki iman Kristen harus meneladani apa yang disampaikan Paulus kepada Timotius dalam 2 Timotius 2:3-7, dimana sebagai pekerja Kristen harus memiliki kesungguhan hati seperti dedikasi seorang prajurit yang baik, ketaatan pada peraturan dari seorang atlet yang baik dan kerja keras dari seorang petani yang baik. Tanpa hal-hal itu tidak dapat mengharapkan hasil. Tidak ada kemenangan bagi seorang prajurit kecuali jika memberi dirinya kepada keprajuritannya, tidak ada pengalungan bunga bagi seorang olahragawan kecuali mengikuti peraturan dan tidak ada panen bagi seorang petani kecuali jika bekerja keras di ladangnya.(Stott 2015)

\section{Memiliki Iman Yang Dinamis}

Manusia cenderung berbicara tentang iman dalam pengertian yang statis sebagai sesuatu yang dimiliki atau tidak dimiliki. Tapi iman adalah suatu relasi yang penuh kepercayaan kepada Allah, dan sebagaimana semua relasi dalam kehidupan, iman adalah sesuatu yang hidup dan dinamis, yang bertumbuh. Dalam 2 Tesalonika terlihat bahwa doa Paulus sebelumnya agar kasih mereka bisa "bertambah-tambah dan berkelimpahan" (1Tes. 3:12) dan visinya bahwa mereka akan saling mengasihi "lebih bersungguh-sungguh lagi" (1Tes 4:10) akan terwujud. Iman mereka juga bertumbuh.(Stott 2011). Pernahkan Anda merasa bahwa mengikut Yesus terlalu banyak tuntutan lebih dari apa yang pernah Anda harapkan? Timotius mempunyai perasaan yang sama. Sebagai pemimpin yang muda dan lembut, ia menghadapi dua dilemma dari kekurangan diri dan gereja yang penuh masalah. Pada saat yang sama pula, Paulus, bapa rohaninya, sedang di penjara menunggu kematian. Penahanannya jelas mengakibatkan banyak yang meninggalkan imannya. Ini adalah surat terakhir yang di tulis Paulus sebelum dihukum mati. Dari dalam penjara, Rasul Paulus menantang Timotius untuk bertahan (2 Timotius 1:8-2:7) (Sterk 1992).

\section{Sikap Tidak Kompromi}

Dalam banyak bidang kehidupan manusia tergoda melakukan kompromi ketika diperhadapkan pada harga hidup beriman di tengah dunia yang tidak beriman ini. Sebenarnya tidak berimanlah yang mahal harganya, tetapi dalam jangka pendek kelihatannya berbeda.. 
Mazmur 73 adalah cerita tentang seseorang yang "hampir tergelincir" ketika melihat keberhasilan orang yang tidak mengenal Allah. Pemazmur menulis: Tetapi ketika aku bermaksud untuk mengetahuinya, hal itu menjadi kesulitan di mataku, sampai aku masuk ke dalam tempat kudus Allah, dan memperhatikan kesudahan mereka. (Mazmur 73:16-17). Visi pemazmur dipulihkan ketika bergerak dari suatu refleksi yang penuh kecemburuan dan mengasihi diri karena lingkungannya menuju refleksi penyembahan kepada Tuhan dengan memandang sifat dan pekerjaan Tuhan Allah. Menyembah Tuhan, mempelajari Kitab Suci, dan pertolongan dari saudara-saudara seiman serta pertanggungjawaban kepada mereka dapat menolong menyadari akan tipuan dunia dan merasakan kehidupan nyata dengan jelas. Pemazmur keluar dari jalur yang seharusnya ketika matanya beralih dari Allah dan mulai tertuju kepada orang-orang lain disekelilingnya dan ketidaksetiaan mereka. Dan juga orang percaya dapat mengaktualisasikan iman Kristen ditengah budaya era disrupsi tersebut dengan tepat dalam terang penafsiran Firman Allah yang benar (Lola 2019).

Orang percaya yang beriman Kristen juga bisa mengalami masalah dengan membandingkan hidup dengan hidup orang Kristen lainnya. Jika orang beriman Kristen memutuskan cukup puas dengan apa yang sedang dilakukan orang Kristen lain, hasilnya mungkin sebuah kompromi (Lamb 2011). Membangun Karakter Kristiani Sehubungan karakter Kristiani adalah hal yang sangat integral dalam iman Kristen, maka sudah seharusnya pendidikan Kristen mengutamakan pendidikan karakter guna membangun karakter Kristiani yang benar dan tidak menghabiskan waktu untuk menguasai elemen dogma Kristen walaupun juga penting (Nuhamara 2018). Karena pendidikan Kristen memiliki tanggung jawab untuk membangun umatnya berdiri di atas dasar Alkitab agar mencapai kesatuan dan kedewasaan iman serta pengetahuan yang benar tentang Yesus Kristus (Darmawan 2014), Sebab Alkitab itu firman Allah yang perlu dipahami oleh semua orang, (Arifianto 2020b) demi membangun hubungan yang berkenan kepada Allah.

\section{REKOMENDASI PENGEMBANGAN PENELITIAN}

Penulis berharap hasil penelitian ini dapat bermanfaat bagi gereja, lembaga pendidikan dan terlebih kepada keluarga.Kiranya saran atau kritik dapat diberikan kepada penulis oleh semua pembaca agar dikesempatan selanjutnya penulis dapat lebih lagi dalam mengembangkan kemampuan yang telah diberikan oleh Tuhan.Penelitian ini masih dapat dikembangkan dengan melihat relevansi penelitian, dengan fakta-fakta di tahun-tahun selanjutnya, oleh orang-orang yang mau menguji atau mengembangkannya.Kemudian, 
penulis juga berharap kiranya penelitian ini dapat menjadi referensi dari penulis-penulis berikutnya yang sedang menulis tentang topik-topik seputar pembahasan yang ada pada artikel ini.

\section{KESIMPULAN}

Orang percaya yang ber-iman Kristen wajib menghadapi era disrupsi ini dengan berani, cerdas dan tanpa kekhawatiran dengan tetap percaya dan memegang teguh prinsip-prinsip yang terkandung dalam iman Kristen dengan konsisten, sehingga dapat menghadapi dan menjalani bahkan mempengaruhi sesamanya dan lingkungan sekitarnya dimana Tuhan menempatkannya dengan benar sesuai maksud Tuhan menciptakan dan memanggilnya. Iman Kristen diharapkan dapat memberikan interpretasi yang tepat terhadap Firman Allah dan juga dapat memberikan interpretasi kepada dunia era disrupsi. Iman Kristen tidak perlu anti terhadap budaya era disrupsi. Sebaliknya iman Kristen harus dapat menginterpretasikan budaya era disrupsi tersebut dengan tepat dalam terang penafsiran Firman Allah yang benar.(Lola 2019)

\section{BIODATA}

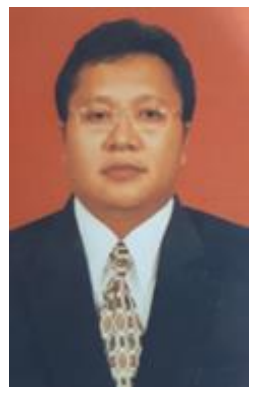

Yakub Hendrawan Perangin angin adalah seorang Dosen tetap di Sekolah Tinggi Teologi Bethel The Way. Selain berprofesi sebagai desen dia juga aktif menululis artikel, kegigihan dalam menulis yang ia lakukan membuahkan hasil yang sangat bagus, dimana sudah ada beberapa artikel yang di terbitkan. dia juga merupakan Hamba Tuhan yang setia dalam pelayanan

\section{Yakub Hendrawan Perangin Angin}

Surel: yakub.hendrawan@sttbetheltheway.ac.id

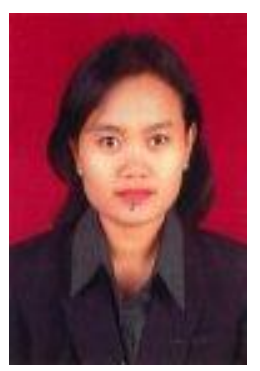

Tri Astuti Yeniretnowati adalah bagian dari keluarga besar Sekolah Tinggi Teologi Ekumene Jakarta. Dia banyak menulis tentang makna-makna teologis yang terdapat di dalam Alkitab dengan membuatnya sebagai jawaban terhadap fenomena-fenomena yang ada pada masa kini.

\section{Tri Astuti Yeniretnowati}

Surel: triastutiyeniretnowati2015@gmail.com 


\section{REFERENSI}

Abineno J.L.Ch. 1993. Pokok-Pokok Penting Dari Iman Kristen. 3rd ed. Jakarta: BPK Gunung Mulia.

Arifianto, Yonatan Alex. 2020a. "Deskripsi Sejarah Konflik Horizontal Orang Yahudi Dan Samaria." PASCA : Jurnal Teologi Dan Pendidikan Agama Kristen 16(1):33-39.

Arifianto, Yonatan Alex. 2020b. "Pentingnya Pendidikan Kristen Dalam Membangun Kerohanian Keluarga Di Masa Pandemi Covid-19.” Regula Fidei Jurnal Pendidikan Agama Kristen 5(2):94-106.

Arifianto, Yonatan Alex, and Asih sumiwi Rachmani. 2020. "Peran Roh Kudus Dalam Menuntun Orang Percaya Kepada Seluruh Kebenaran Berdasarkan Yohanes 16: 13.” Jurnal Diegesis $3(1): 1-12$.

Arifianto, Yonatan Alex, Reni Triposa, and Daniel Supriyadi. 2020. "Shamayim : Jurnal Teologi Dan Pendidikan Kristiani Menerapkan Matius 5 : 13 Tentang Garam Dunia Di Tengah Era Disrupsi." 1(1):92-106.

Baker, D. .. \&. R. Butarbutar. 1991. Janji Tuhan Dan Jawaban Kita. 2nd ed. Jakarta: Persekutuan Pembaca Alkitab.

Baker, Donald. 2013. Filipi: Yesus Sumber Sukacita. 2nd ed. Jakarta: Literatur Perkantas.

Bashori, Khoiruddin. 2018. "Pendidikan Politik Di Era Disrupsi." Sukma: Jurnal Pendidikan 2(2):287-310.

Bridges, Jerry. 2013. Growing Your Faith (Tumbuhkan Imanmu). 1st ed. Bandung: Pionir Jaya.

Darmawan, I. Putu Ayub. 2014. "Pendidikan Kristen Era Postmodern.” Jurnal Simpson: Jurnal Teologi Dan Pendidikan Agama Kristen (Setiawan 2007):31-40.

Diana, Rahmi, Faidatul Hasanah, Restu Presta Mori, Nurul Mailani. 2019. "Pendidikan Karakter Berbasis Multiple Intelligence Sebagai Desain Pembelajaran Di Era Disrupsi.” Pp. 1-6 in Prosiding Konferensi Pendidikan Nasional "Strategi dan Implementasi Pendidikan Karakter pada Era Revolusi Industri 4.0.”

Diana, Ruat. 2019. "Prinsip Teologi Kristen Pendidikan Orang Tua Terhadap Anak Di Era Revolusi Industri 4.0.” BIA - Jurnal Teologi Dan Pendidikan Kristen Kontektual 2(No. 1, Juni 2019):2739.

Echols, John M. \&. Hassan Sadily. 1990. Kamus Inggris Indonesia. 19th ed. Jakarta: Gramedia.

Frazee, Randy \&. Robert Noland. 2016. Berpikir, Bertindak, Menjadi Seperti Yesus. 1st ed. Yogyakarta: Yayasan Gloria.

Gea, Yanti Imariani. 2020. "Iman Orang Percaya Dalam Menghadapi Tantangan Dan Pergumulan Hidup.” Immanuel: Jrnal Teologi Dan Pendidikan Kristen 1(1):25-32.

Groome, Thomas H. 2017. Christian Religious Education - Pendidikan Agama Kristen. 6th ed. Jakarta: Gunung Mulia. 
Horsfall, Tony \&. Debbie Hawker. 2020. Tangguh Dalam Kehidupan Kuat Dalam Tuhan. 1st ed. Yogyakarta: Katalis.

Jawamara, Markus Ndihi. 2020. "Memahami Konsep Iman Dan Perbuatan Menurut Yakobus: Suatu Study Eksegesis Yakobus 2:26.” SESAWI: Jurnal Teologi Dan Pendidikan Kristen 1(2):111-25.

Lamb, Richard. 2011. Menjadi Murid Yesus Di Kehidupan Nyata. 2nd ed. Jakarta: Literatur Perkantas.

Lola, James A. 2019. “Iman Kristen Dan Budaya Popular." Visio Dei: Jurnal Teologi Kristen $1(1): 101-21$.

Nathanael, Octavianus, Sekolah Tinggi, Teologi Misi, William Carey, and Sumatera Utara. 2020. "Implikasi Iman Dan Mujizat Di Perjanjian Baru Dalam Perkembangan Gereja Elim Kristen Indonesia." HAGGADAH: Jurnal Teologi Dan Pendidikan Kristen 1(1):42-54.

Njo, Saferinus. 2020. "Peran Maria Sebagai Bunda Dan Guru Imamat Dalam Pembinaan Imam Di Era Revolusi 4.0.” Studia Philosophica et Theologica 20(1):32-51.

Nuhamara, Daniel. 2018. "Pengutamaan Dimensi Karakter Dalam Pendidikan Agama Kristen." Jurnal Jaffray 16(1):93.

panuntun, daniel fajar. 2020. "Misi Apologetika Kristen Online Di Era Diruspsi." Jurnal Apostolos 2(1).

Poerwadarminta, W. J. .. 1985. Kamus Umum Bahasa Indonesia. 8th ed. Jakarta: PN Balai Pustaka.

Rahayu, Ratih. 2018. "Mengupas Buku Terbaru Rhenald Kasali: Self Disruption.” Warta Ekonomi, June.

Ronda, Daniel. 2019. "Kepemimpinan Kristen Di Era Disrupsi Teknologi.” Evangelikal: Jurnal Teologi Injili Dan Pembinaan Warga Jemaat 3(1):1.

Sabdono, Eras. 2017. Menantang Zaman. 1st ed. Jakarta: Rehobot Literature.

Sabdono, Eras. 2018a. Harga Iman. 1st ed. Jakarta: Rehobot Literature.

Sabdono, Eras. 2018b. Kehidupan Dalam Iman. 1st ed. Jakarta: Rehobot Literature.

Soedarmo, R. 2011. Ikhtisar Dogmatika. Cetakan 17. Jakarta: BPK Gunung Mulia.

Sproul, R. C. 2018. Kebenaran-Kebenaran Dasar Iman Kristen. Malang: Literatur SAAT.

Sterk, Andrea \&. Peter Scazzero. 1992. Karakter Kristen. 2nd ed. Jakarta: Literatur Perkantas.

Stott, John. 2011. 1 \& 2 Tesalonika Hidup Di Zaman Akhir. 1st ed. Jakarta: Literatur Perkantas.

Stott, John \&. Lin Johnson. 2015. Berdiri Teguh Dalam Kebenaran. 2nd ed. Jakarta: Literatur Perkantas.

Surabaya, Staf Perkantas. 2016. Pembinaan Dasar. 5th ed. Surabaya: Literatur Perkantas Jawa Timur. Sutrisna, Wibawa. 2018. “Pendidikan Dalam Era Revolusi Industri 4.0.” Academia.Edu 8(2):1-10. 
Widiatna, Alexius Dwi. 2020. "TRANSFORMASI PENDIDIKAN CALON KATEKIS DAN GURU AGAMA KATOLIK DI ERA DIGITAL.” JPAK: Jurnal Pendidikan Agama Katolik 20(2):6682 .

Zaluchu, Sonny Eli. 2020. “Struktur Artikel Untuk Jurnal Ilmiah Dan Teknik Penulisannya.” Pp. 1-21 in Strategi Menulis Jurnal Untuk Ilmu Teologi, edited by S. E. Zaluchu. Semarang: Golden Gate Publishing Semarang. 